FIU Law Review

Fall 2015

\title{
Religious Sex Status and the Implications for Transgender and Gender Nonconforming People
}

Shawn Markus Crincoli

Touro College Jacob D. Fuchsberg Law Center

Follow this and additional works at: https://ecollections.law.fiu.edu/lawreview

Part of the Other Law Commons

Online ISSN: 2643-7759

\section{Recommended Citation}

Shawn M. Crincoli, Religious Sex Status and the Implications for Transgender and Gender Nonconforming People, 11 FIU L. Rev. 137 (2015).

DOI: https://dx.doi.org/10.25148/lawrev.11.1.10

This Article is brought to you for free and open access by eCollections. It has been accepted for inclusion in FIU Law Review by an authorized editor of eCollections. For more information, please contact lisdavis@fiu.edu. 


\title{
Religious Sex Status and the Implications for Transgender and Gender Nonconforming People
}

\author{
Shawn Markus Crincoli*
}

"Hashem [God] knows I'm a girl," twelve-year old Miryam² told her mother, coming out to her as transgender and explaining why she could not go through with her upcoming bar mitzvah. The bar mitzvah ceremony celebrates the time when a Jewish boy comes of age and becomes a man within the Jewish people. Miryam had become depressed and withdrawn, refusing to go to shul (the synagogue) and struggling at the Jewish day school while preparing for this impending event.

Miryam's supportive mother cancelled the bar mitzvah and helped her daughter begin the process of socially and then medically transitioning. Miryam describes how prior to her transition, "I really didn't like [going to synagogue] because I always had to sit on the men's side of the mechitza and couldn't be with the women."

Unfortunately, after Miryam transitioned, the rabbi of the lone Orthodox synagogue in their tight-knit midwestern community delivered the ultimatum that she could "come and sit with the boys and wear a suit or just can't come" to the synagogue. Miryam also switched schools from the local Jewish day school to a public school in a district familiar with the needs of transgender students. She is a happy young woman "living her authentic life." Regrettably, "happiness has also come at a cost in terms of the Jewish life of her whole family" and she misses the traditions of Orthodox Jewish life.

The prognosis of happiness is murkier for Ben, ${ }^{4}$ a Catholic child being raised in Philadelphia. ${ }^{5}$ From the time he was a toddler, Ben demonstrated gender nonconforming behavior. At the age of four, he told his father that he wanted to be a girl and did not want to grow up. Though there is no way to be certain that Ben is a transgender girl, these comments are indicative of

\footnotetext{
Associate Professor of Law, Touro College Jacob D. Fuchsberg Law Center.
}

1 Debra Nussbaum Cohen, Orthodox Child's Transgender Journey from Moshe to Miryam, FORWARD (June 12, 2014), http://forward.com/articles/199978/orthodox-childs-transgender-journeyfrom-moshe-to/?p=all\#ixzz34VdAv84T.

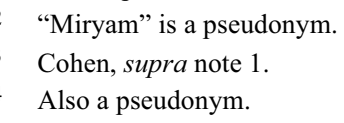

5 Celeste McGovern, Boys Will Be Girls?, National Catholic Register (July 1, 2008), www.ncregister.com/site/article/15350. 
a child who is, at a minimum, expressing discomfort or incongruence between gender identity and the expected gender role accompanying the assignment of sex at birth. ${ }^{6}$

Mental health experts providing guidance for parents of gender nonconforming children would recommend that Ben be allowed to lead in exploring gender identity and not be made to feel that his preferred gender expression is wrong or shameful. ${ }^{7}$ As Ben's depression and non-conformity continued, his parents sought treatment. Unfortunately, they selected a Catholic psychiatrist who counsels "individuals with gender identity disorder to appreciate the bodies they were born in." premised in Catholic theology that gives primacy to the physical body and rejects the scientific and medical consensus regarding gender identity. The psychiatrist disputes the medical best practices indicating that hormones and surgery are medically necessary treatment for many transgender people, claiming that "effective therapy brings to an end the suffering of these children."

Following the advice of the psychiatrist, Ben's parents are treating his gender dysphoria by directing him toward stereotypical masculine activities and requiring him to recite in his daily prayers, "Thank you, God, for making me a special boy." According to Ben's father, his child is happier and "you would think he is a well-adjusted happy boy. I just know from the bottom of my heart that we are on the right track. I thank God that we are Catholic." 10

America is currently experiencing a "transgender moment." $\mathrm{A}$ cultural reckoning has launched the existence of and experiences of (some) transgender people into the forefront of a national dialogue regarding sex,

6 Sissies AND TOMBoys: GeNDER NONCONFORMity AND HomoseXual CHILDHOOd (Matthew Rottnek ed., 1999) (exploring the likelihood that gender nonconforming children will grow up to be gay or lesbian, as opposed to transgender).

7 Diane Ehrensaft, Listening and Learning from Gender-Nonconforming Children, 68 Psychoanalytic Study of the Child 28 (2015); Diane Ehrensaft, Gender Born, Gender MADE: RAISING HEALTHY GENDER-NONCONFORMING CHILDREN (2011); Emily W. Kane, "No Way My Boys Are Going to Be Like That!" Parents' Responses to Children's Gender Nonconformity, in Kaleidoscope of Gender: Prisms, Patterns, AND Possibilities 173-179 (Joan Z. Spade \& Catherine G. Valentine eds., 2 d ed. 2008); Edgardo J. Menvielle, Catherine Tuerk, Ellen C. Perrin, To the Beat of a Different Drummer: The Gender-Variant Child, 22 CONTEMPORARY PEDIATRICS 38 (2005); Nicole Crawford, Understanding Children's Atypical Gender Behavior: A Model Support Groups Helps Parents Learn to Accept and Affirm Their Gender-Variant Children, 34 MONITOR 40 (2003).

8 Celeste McGovern, Boys Will Be Girls?, National Catholic Register (July 1, 2008), www.ncregister.com/site/article/15350.

$9 \quad I d$.

$10 \quad I d$.

11 See e.g., Brandon Griggs, America's Transgender Moment, CNN (June 1, 2015), www.cnn.com/2015/04/23/living/transgender-moment-jenner-feat/index.html. 
gender, and gender identity. This increased visibility of transgender and gender non-conforming people is occurring in parallel with an increased awareness and acceptance of lesbian, gay, bisexual, transgender, and queer (LGBTQ) rights as civil rights, as human rights.

Meanwhile, the strongest opposition to equality for LGBTQ people within the United States stems from religious organizations and individuals. ${ }^{12}$ Yet while there has been robust debate about homosexuality and religion, particularly in the context of those who oppose same-sex marriage, and while religious leaders and organizations often favor policies that discriminate against transgender or gender nonconforming people, a full exploration of these underlying religious beliefs remains unexamined.

At the core of this inquiry is how religious doctrines or philosophy treat assignment and reassignment of sex. Or in other words-how is a person understood to be male or female (or even non-binary gendered) within the framework of a religious denomination? And how can an individual change this designation if the one assigned to them does not match the underlying gender identity?

In this essay, I introduce the concept of "religious sex status" to refer to the legal sex as understood within the purview of religious thought, philosophy, or law. I employ a comparative approach to contrast the complexity of legal sex assignment within the United States to the existence and designation of religious sex status in traditional Judaism.

From a human rights perspective, religion and people of faith are the villains in the stories presented in the beginning of this essay. Miryam's rabbi and Ben's psychiatrist and parents are expressing a core belief: religion dictates "sex status" for each person without regard for gender identity. They are interpreting Orthodox Judaism and Catholicism, respectively, to unequivocally hold that natal sex assignment reflects ontological truth. This conception of religious sex status is a legal or philosophic designation of sex stemming from theology, akin to a secular designation of legal sex assignment. There is a correlation between affiliation with certain religious denominations, such as evangelical Christianity, Catholicism or Orthodox Judaism, and negative attitudes toward homosexuality. There is also a strong correlation between possessing negative attitudes toward LGBTQ people as a group and possessing negative attitudes toward transgender people in specific. However, there is no definitive guide to how various religious denominations view transgender and gender non-conforming people or acts

12 Jay Michaelson, Redefining ReLigious Liberty: THE COVERT CAMPAign Against CiviL RIGHTS (2013), www.politicalresearch.org/wp-content/uploads/downloads/2013/04/PRA_RedefiningReligious-Liberty_March2013_PUBLISH.pdf. 
of transition.

Religious perspectives on transgender people are not necessarily analogous to religious beliefs about gay and lesbians or same-sex marriage. However, considerations of identity and conduct arise in both the context of LGBTQ people and transgender people.

There are different types of religious beliefs that can be incongruent with recognizing and affirming the gender identity of transgender or gender non-conforming people. One set of beliefs considers identity and sex status. The other set of beliefs focus on conduct, particularly as related to gender affirmation.

The modern scientific and medical consensus regarding gender identity is inapposite with beliefs in the existence of an underlying religious sex status within each person that is fixed at birth. ${ }^{13}$ There are numerous religious denominations that posit a religious sex status that is biologically determined and fixed at birth. It should be noted some religious denominations do consider the potential for religious sex status to shift via acts of transition or would consider gender identity to be the source of this sex status, not biology at birth.

Within the United States, roughly half the population identifies as affiliated with evangelical protestant or Catholic denominations. Both Catholicism and evangelical Christianity often define sex roles and gender expression in a manner that either directly or indirectly determines religious sex status based on natal sex. Orthodox Judaism, Islam, and Mormon doctrine share similar tenets. To date, there is limited research on how many Americans hold these specific religiously prescribed beliefs concerning transgender people, and not everyone affiliated with a denomination agrees with every belief religiously dictated.

Nonetheless, this creates a large pool of individuals who may reject the gender identity of transgender people on religious grounds and understand transgender and gender non-conforming people ontologically as being only their natal, biological sex. Some adherents of these beliefs refuse to interact with transgender individuals in any manner that recognizes their gender identities. A more accommodating religious perspective may allow for respectful interactions with transgender people in their affirmed genders, while still holding the underlying sex status of the individual as that which was assigned at birth for any religious or ritual purposes, including any eligibility for the ministry or sex status for marriage.

13 See WORLd Professional AsSOCIATION FOR TRANSGENDER HEAlth (WPATH),

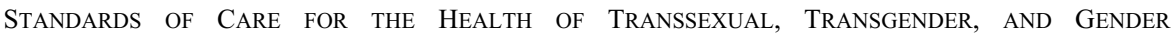
NONCONFORMING PEOPLE (2012), www.wpath.org/uploaded_files/140/files/Standards\%20of \%20Care, $\% 20$ V7\%20Full\%20Book.pdf [hereinafter STANDARDS OF CARE]. 
Beliefs in a fixed sex status often lead to support for reparative or conversion therapy for transgender individuals. For example, Christian leaders working for the Family Research Council and the National Organization for Marriage explain that treatment for transgender people should be "to help men and women become comfortable with their actual biological sex" and "to respect ... how they were born." 14

These religious beliefs are wholly inconsistent with the World Professional Association for Transgender Health's Standards of Care ${ }^{15}$ and the consensus of the medical and scientific community that transitionrelated treatments are medically necessary for those suffering from gender dysphoria, the distress that many transgender people experience when forced to live as the sex they were assigned at birth.

\section{ASSIGNMENT OF SEX WithIN THE UNITED STATES}

In the United States, when a baby is born, the doctors and nurses assign sex based on external genitalia. This assignment is then typically recorded on the child's birth certificate. Even though this recording is a ministerial act, ${ }^{16}$ this designation may have serious consequences in how American law will define and understand the sex of that individual.

In cases of ambiguous genitalia, the medical providers in much of the twentieth century have assigned the sex that best fits the capabilities of doctors to surgically alter the child's genitals to appear more readily as male or female. ${ }^{17}$ In recent years, health practitioners have delayed sex assignment, while extensive medical testing attempts to "reveal" the infant's biological sex beyond what is visible to the naked eye. Best practices now dictate that doctors not intervene until a child is old enough to express a gender identity and to consent to surgery or other treatment altering the body, and that intersex people not be forced into binary categories of male/female if their gender identity is not binary. ${ }^{18}$

Transgender people often suffer because the sex markers on their birth certificates do not match their gender identities. ${ }^{19}$ However, this birth-based assignment alone is not understood to be solely determinant of legal sex

14 Ariana Eunjung Cha, Ban Lifted on Medicare Coverage for Sex Change Surgery, WASHINGTON POST (May 30, 2014), www.washingtonpost.com/national/health-science/ban-lifted-onmedicare-coverage-for-sex-change-surgery/2014/05/30/28bcd122-e818-11e3-a86b-362fd5443d19_story .html.

15 See STANDARDS OF CARE, supra note 13.

16 Lisa Mottet, Modernizing State Vital Statistics Statutes and Policies to Ensure Accurate Gender Markers on Birth Certificates: A Good Government Approach to Recognizing the Lives of Ttransgender People, 19 MiCH. J. OF GENDER \& L. 373 (2013).

17 Julie A. GreEnBerg, InTERSEXuAlty AND the LAW: Why SEX MATters (2012).

18 Id.

19 Dean Spade, Documenting Gender, 59 HASTINGS L.J. 731 (2008). 
under American law. In fact, in the United States, there is no singular definition of what makes an individual legally a man or a woman. Different jurisdictions and different policy-makers within these jurisdictions rely on different aspects of biology, identity, and legal documents to define what constitutes legal sex and for what purpose. ${ }^{20}$ The role of the birth certificate as a recording of sex assignment at birth is mitigated in those locations that permit this document to be altered as part of the process of socio-legal sex reassignment. $^{21}$

The assignment of sex at birth lies in the locus of law (via recording on the birth certificate), medicine (the determination by nurses or doctors), and society ("It's a boy/girl!" introduction to family and community). As a result, sex reassignment in the United States often matches this triadic approach. Changing a person's sex designation in the eyes of the law, either within identity documents or in categorizing the individual for legal purposes, often requires social and/or medical transition. The World Professional Association for Transgender Health (WPATH) recommends in the Standards of Care that medical aspects of transition ought not to be linked to the understanding of legal sex, including the right to any legal or identity document. ${ }^{22}$ Divorcing legal sex from medical treatment would further the important goal of depathologizing trans people. However, in most jurisdictions in the United States, legal transition, an amorphous entity in and of itself, remains connected to medical transition.

More critically, transgender and intersex people often suffer because of the societal expectation that external genitalia should determine legal sex assignment, even when the law does not say that it does. ${ }^{23}$ Via the lens of legal realism, American judges and lawyers functionally understand that the law often acts to assign, categorize, and create, rather than identify that which independently exists. Nonetheless, the charade of judge as law-finder rather than law-maker, especially when the answer is supposed to rest with scientific and medical experts, allows actors within the legal system to perpetuate the public misunderstanding that innate biology defines legal sex; innate biology all too often means the external presence or absence of a penis.

21 See Mottet, supra note 16.

22 See STANDARDS OF CARE, supra note 13.

23 See Spade, supra note 19. 


\section{CONSEQUENCES OF THE UNCERTAIN LEGAL SEX STATUS IN THE UNITED STATES}

Legal sex in the United States is an unusual conceit. It typically does not matter or even appear to exist ... until it does. Greenberg notes that "a person's legal sex is significantly less important now than it has been at any other time in history" because of the "gradual disappearance of sex based distinctions in our laws." 24

When some law or policy requires that a person be categorized by sex, such as for the purpose of marriage or housing in jail or a shelter, the absence of a clear and universal demarcation lends itself to diverse, and, often discriminatory, practices. As Spade discusses, the administrative process of policing gender is hardly distributed at random. ${ }^{25}$

Transgender people who enjoy passing privilege and perhaps other societal privileges, such as race and class, can go about daily lives without reflecting much on whether they even have one legal sex recognized by American law. A trans woman born in Florida and living in Washington may have a birth certificate with a male sex marker, yet other identification and citizenship documents, such as a driver's license, passport, and court order, that list her as female. If she has socially and medically transitioned, including genital reconstruction surgery, she may easily navigate a world in which she is seen as a woman in the societal cis-heteronormative framework.

However, transgender people, no matter how privileged, must also grapple with the legal uncertainties that come with no nationalized recognition of sex or gender. ${ }^{26}$ Best legal practices suggest an expensive "belts and suspenders" 27 approach to protect from future legal attack because "a person's legal sex could change as a state line is crossed" or even "vary within a state depending on whether the state is determining the ability to marry, to use public restrooms, or to carry a driver's license ... with a name and sex indicator that match the person's gender identity." 28

Significantly, so many of the questions in which legal sex arises in America are in the relational or communal context. Legal sex matters, for example, when the person wants to marry or must be housed with others. In a worst case scenario, custody of children can hinge on how an adversarial

24 GREENBERG, supra note 17 , at 48.

25 Dean Spade, Normal Life: Administrative Violence, Critical Trans Politics, and THE LIMITS OF THE LAW (2011).

26 Though it is beyond the scope of this paper, recognition of a nationalized legal sex is often no panacea to trans or intersex people either.

27 JENNIFER L. LEVI, TrAnSGENDER FAMiLy LAW: A Guide to EFFECTIVE AdVOCACy (2012).

28 GREENBERG, supra note 17 , at 49. 
ex-spouse can benefit from the post-hoc sex status determination that legally operates to remove parental rights, such as in Kantaras $v$. Kantaras. ${ }^{29}$

Spade's harsh critique of the structural violence inherent within the legal system against transgender people explores the consequence of making legal sex labeling an act of violence and control that is perpetuated by empowered societal forces against the individual. ${ }^{30}$ For example, public debates over the access that transgender people have to bathrooms and locker-rooms may be understood as a conflict between those who view these spaces as individualized, functioning as a matter of the human right of the person to health and safety, versus communal, functioning as an effort to define who "counts" in the group of men or women and protecting the rights of the cis-gendered majority to exclude those who are seen as other.

\section{RELIGIOUS SEX STATUS WiTHIN TRADITIONAL JEWISH LAW}

In Orthodox Judaism, when a child is born, religious purposes dictate that the family and community understand the child's sex status. Halakha (Jewish law) requires fathers to circumcise their sons (or typically hire a trained agent, the mohel, to do so for them) on the babies' eighth day of life. As a result, time is of the essence in assigning sex.

Jewish communities have always had children with intersex conditions. For example, Ashkenazi (Eastern European) Jews have a high prevalence of congenital adrenal hyperplasia $(\mathrm{CAH})$. In cases of ambiguous genitalia, the eight day time clock to assign sex creates pressure for Jewish medical ethicists, an elite group of rabbis who are recognized as authorities in halakha and trained in biology, medicine, or related sciences, to determine whether the infant should be treated as a boy or a girl under Jewish law. While delays are permitted, there is significant communal pressure to hold circumcision ceremonies at the proper time, and the delays are understood communally to indicate an illness or "problem" with the infant.

All but one Orthodox rabbinic authority consider legal sex in Judaism to be fixed at birth. ${ }^{31}$ Even though some Jewish traditional texts discuss non-binary sexed people, modern Jewish law operates with a sex binary; the only options for religious sex status are male or female. ${ }^{32}$

29 Kantaras v. Kantaras, 884 So. 2d 155 (Fla. Dist. Ct. App. 2004).

30 SPADE, supra note 25.

31 J. David Bleich, Transsexual Surgery, in JEwish Bioethics 209-14 (Fred Rosner \& J. David Bleich eds., 1989); Appendix: Sex Change Operations and Their Effect on Marital Status: A Brief Comparison, JEWISH LAw, www.jlaw.com/Articles/maternity_appendix.html.

32 BALANCING ON THE MEChitZA: TRANSGENDER IN JEWISH COMMUNity (Noach Dzmura ed., 2010); Rabbi Elliot Kukla, Terms for Gender Diversity in Classical Jewish Texts, TRANSTORAH (2006), 
Because traditional Jewish law or Catholicism, like many religious teachings, approach the legal category of sex from a positivist perspective, they rely on an essentialist perspective that there is an existing truth, and this truth includes the classification of an individual based on sex.

This can be contrasted with a realist perspective of legal sex, which would follow a social constructionist theory that sex status is not created until decision-makers impose or assign a sex status to an individual. Religious sex status is an innate phenomenon to be uncovered by the world, rather than something that is created or constructed through the act of assignment.

What makes a person male or female according to halakha? Orthodox rabbis do not agree. Traditionally, Jewish decision-makers had no other tools or knowledge but the ability to observe external genitalia. Over the past forty years, though, "opinion has been divided over whether to apply a genotypic or phenotypic formula" to cases of intersexuality. In other words, some authorities have ruled that genetic makeup (i.e., the XY chromosome) should dictate whether an individual is male under halakha. Others have reached decisions based on the external appearance of the body. Though these decisions are often made privately, there are a few responsa that serve as source material of the competing views on sex status within halakha.

In identifying why the genotypic rationale emerged, Hillel Gray posits that the rabbis in the 1970s and 1980s viewed genetic composition as more innate and authentic to the individual than the external body. ${ }^{33} \mathrm{He}$ has provided evidence that Orthodox authorities favoring the genotypic approach were aware of the connection between transsexuality and intersexuality and fearful of adopting a phenotypic approach that would serve as the basis for recognizing the validity in halakha of sex reassignment in trans people.

Individuals with androgen insensitivity syndrome are treated according to phenotype in Orthodox communities, an inconsistency which suggests that the transphobic motivation played a role in the pro-genotypic decisions.

The one Orthodox rabbi who has publically validated the legal meaning of sex reassignment in halakha did rely on a phenotypic approach to understanding sex status. Rabbi Eliezer Yehuda Waldenberg, known as the Tzitz Eliezer, wrote two responsa relevant to the issue of sex reassignment. Waldenberg was a leading authority in Jewish medical ethics in the twentieth century and served as a judge on the Supreme Rabbinical Court in Jerusalem.

\footnotetext{
www.transtorah.org/resources.html.

33 Hillel Gray, Not Judging by Appearances: The Role of Genotype in Jewish Law on Intersex Conditions, 30 SHOFAR 126, 126-48 (2012).
} 
The first responsum deals with organ transplants and raises the hypothetical case of "significant/organic alterations of the body, such as a person who changes from male to female, or vice versa" through a rare surgery that "is done in special cases." "34

Waldenberg discusses two outcomes in halakha concerning this "woman who has many signs of being a man which are apparent to the visual sense" and, therefore, "is truly a man." First, the man does not need a writ of divorce from a husband (no longer being the wife of a man). ${ }^{35}$ Second, this man would say a morning blessing praising God "who has changed me into a man," as opposed to the blessing either cis-men recite ("who has not made me a woman") or that cis-women replace in prayer ("who made me according to his will"). ${ }^{36}$ Each of these rulings is premised on the hypothetical trans man having a male sex status within halakha.

A doctor read the first responsum and sent Rabbi Waldenberg a letter asking about a case in the hospital where he worked. The doctor describes a baby who was born with mostly female appearing genitals-labia and what appeared to be a clitoris. Yet the baby had a single testicle in one of the labia. Genetic testing determined that the baby had XY chromosomes. Invasive testing found no male organs inside the body. This suggests the infant had an androgen insensitivity syndrome. The doctor wanted to know if halakha permitted him to surgically alter an XY male into a functional female, and if it was permissible to remove the singular testicle, in light of the Biblical prohibition against castration.

In the responsum answering the doctor's questions, Rabbi Waldenberg announced that halakha only focused on external organs that can be seen by the naked eye. So the internal organs, or lack thereof, was irrelevant. Since the organs appeared female, the baby should be treated as a girl by Jewish law.

The combination of these responsa creates a clear, minority opinion in halakha that phenotype is determinant, not genotype, and the act of changing external organs has the legal effect of changing sex status in halakha.

I should note here that there is a difference between permitting the act of transition (or, more accurately, acts of transition) and recognition of a change in sex status. Waldenberg is not specifically permitting (medical) transition, so there is no official Orthodox authority for a trans person to do so. A full discussion of the prohibitions in halakha on medical treatments or

34 Beth Orens, Judaism and Gender Issues, in BALANCING ON THE MECHITZA: TRANSGENDER IN JEWISH COMMUNITY 224, 224-28 (Noach Dzmura ed., 2010).

$35 \quad I d$.

36 Id. 
any other gender affirming act is beyond the scope of my remarks.

Dzmura describes Orthodox trans men and women he interviewed who state that privately they have received permission from other rabbis to undergo medical transition, including sex reassignment surgery, or that the rabbis have knowingly accepted a change in sex status according to halakha ${ }^{37}$ In one instance, the rabbi even promised that he would officiate a hypothetical wedding between an Orthodox transgender woman and a man.

The Conservative denomination's philosophy toward halakha is that Jewish law can and should be more dynamically interpreted. Nonetheless, historically, the Conservative movement has been slow to adopt egalitarian and pro-LGBTQ practices.

In 2003, the Committee on Jewish Law and Standards of the Rabbinical Assembly, the primary decision-making body for the Conservative movement, issued a responsum determining that "only those who have undergone full SRS [sex reassignment surgery] (including phalloplasty/vaginoplasty) are to be considered as having changed their sex status." ${ }^{38}$ This decision considers the traditional Jewish sources alongside the WPATH (then Harry Benjamin) Standards of Care in effect at the time. The rationale for the ruling is based in a phenotypic understanding of sex status in halakha.

The responsum also declines to rule on whether sex reassignment surgery should be viewed as permitted within halakha. It balances the pain and suffering of gender dysphoria with traditional Jewish teachings against castration and other medical intervention, and then chooses to leave this question for another time, when the Conservative rabbis felt that they could adequately judge the long-term effectiveness of surgery.

To summarize, transgender people, and often intersex people as well, are given a biologically-based sex status under Jewish law that is incongruent with who they are, and under the majority position in halakha, they are granted no legal mechanism within the religion for affirming gender identity. The most progressive decisions regarding the ability to change sex status within halakha, both in Orthodox (Waldenberg) and Conservative (the Committee) Judaism, require surgery to achieve a phenotypic change in appearance of the genitalia. Divergent opinions suggest that even if an individual follows the teachings of a community or Rabbinical leader that accept the opportunity to affirm gender identity,

37 Noach Dzmura, Intersexed Bodies in Mishnah: A Translation and an Activist's Reading of Mishnah Androgynos, in BALANCING ON THE MEChitZA: TRANSGENDER IN JEWISH COMMUNITY 163 (Noach Dzmura ed., 2010).

38 Rabbi Mayer E. Rabinowitz, Status of Transsexuals, COMMITTEE ON JEwiSH LAW AND STANDARDS OF THE RABBINICAL ASSEMBLY (May 11, 2003), www.rabbinicalassembly.org/jewish-law/ committee-jewish-law-and-standards/even-haezer. 
others who disagree will not accept this determination concerning sex status. The consequence of this religious sex status determination is far reaching in terms of individual and communal practice, such as inclusion in prayer quorums or for marriage.

\section{CONCLUSION}

The modern scientific and medical consensus regarding gender identity is inapposite with beliefs in the existence of an underlying religious sex status within each person that is fixed at birth. There are numerous religious denominations that posit a religious sex status that is biologically determined and fixed at birth. It should be noted some religious denominations do consider the potential for religious sex status to shift via acts of transition or would consider gender identity to be the source of this sex status, not biology at birth. Even so, people with a non-binary gender may be left out of the recognition process as well.

The determination of religious sex status matters to how fully transgender people can participate in religious community and worship. It also matters in how transgender people of faith view themselves.

Given that there is no one designation of legal sex in the United States, it further opens the door for legal and religious decision-makers to rely on their own religious beliefs to determine how to assign or re-assign sex. This potentiality both causes and contributes to the discrimination that transgender people already experience. 